\title{
Charismatic Leadership Research Based on Behavior of Emperor Taizu of Song
}

\author{
Xiaodong Zhao
}

Tianjin University of Technology, Tianjin 300834 China

\author{
408255003@qq.com
}

\begin{abstract}
Charismatic leadership and team performance has always been one of the hot research of organization behavior in recent years, it received the attention of scholars and managers. As a typical representative of charismatic leadership, emperor Taizu of Song, there is little research about his leadership behavior. This paper bases on the leadership behavior of emperor Taizu of Song to explore his charisma.
\end{abstract}

Keywords: Emperor Taizu of Song; charismatic leadership; leadership behavior; charisma.

\section{基于宋太祖行为的魅力型领导研究}

\author{
赵晓栋 \\ 1. 天津理工大学, 天津 中国
}

摘 要: 魅力型领导理论一直是近年来组织行为学研究的热点问题之一, 受到学者和管理者广 泛关注。宋太祖赵匡胤作为鬼来力型领导的典型代表, 但对其领导行为的研究却少之又少。本 研究基于宋太祖的领导行为, 探究其魅力特质。

关键词: 宋太祖; 魅力型领导; 领导行为; 魅力特质

\section{1. 前言}

魅力型领导理论是领导风格理论的一种, 作为人力资源领域近三十年来广泛研究的热点之一。 魅力型领导的行为特征包括几方面: 能够向下属清楚的描述一个未来愿景, 激发员工的内在 和外在需求, 将组织目标与员工的个人目标联系在一起, 发挥下属员工的热情和活力; 拥有 高度的自信, 为下属树立一个成功的形象, 特别是在组织处于危机的时刻做出决策, 坚定组 织的信心; 善于与下属进行沟通, 建立强有力的纽带, 在组织中营造出轻松愉快的沟通氛围, 能够充分展现自己的才能, 运用语言技巧使下属可以心甘情愿的为组织付出; 富有敏锐的洞 察力, 对环境的敏感, 时刻提出新奇的看法和建议, 做改革最坚定的执行者。魅力型领导最 成功之处在于, 激励下属。鬼米力型领导能够树立强有力的形象, 为组织明确愿景目标, 并且 善于和下属进行沟通。鬼米力型领导理论在 20 世纪 70 年代提出, 但翻阅我国历史, 魅力型领 导每朝每代都有，宋国开国皇帝赵匡乣就是一位典型的鬼米力型领导者。

赵匡胤字元朗, 生于 927 年, 卒于 976 年。在他出生的年代, 大唐王朝经历了 “安史之乱” 后, 渐渐走向衰落, 藩镇割据纷纷自立为国, 中原地区相继建立了后梁、后唐、后晋、后汉、 后周, 长江流域附近同时存在了 10 个小国, 史称 “五代十国”。赵匡胤在乱世中建立了宋王 朝, 结束了唐朝后期以来的乱世, 开创了三百年的宋朝。赵匡胤的成就固然与当时的历史条 件有关, 但其自身的人格和行为鬼米力却是至关重要的。 


\section{2. 宋太祖的领导行为}

2. 1 . 建立愿景目标

魅力型领导的首要任务是能够向下属清楚的描述一个未来愿景, 这种愿景表达了一个组织长 期的诉求。赵匡胤称帝时, 百姓纷纷认识祸乱不免, 但赵匡胤的种种做法打消了百姓的疑虑。 经历了陈桥兵变, 黄袍加身的政变后, 赵匡胤率领大军进入京城, 并且下令不得剽掠百姓, 抢劫府库, 诛杀旧朝大臣, 违者灭族。史书记载, 在赵匡胤入京之日, 集市照常做生意, 这 足以说明赵匡胤人格鬼力。赵匡胤建立宋朝之后仍重用旧朝重臣, 并没有丝毫怠慢, 相反对 于那些阿诚奉承之人, 宋太祖绝不重用。在陈桥兵变中, 大军离开陈桥驿, 大军经过陈桥门, 守将不肯开门, 坚持大军有皇帝的诏书才行。赵匡胤出人意料的选择绕行封丘门, 而没有选 择用强。宋太祖禅位后, 重赏了陈桥门的守将, 却杀了封丘门的守将。称帝后的赵匡胤并没 有对后周柴氏子孙屠翏, 相反赵匡胤颁布诏书: 柴氏子孙有罪不得加刑, 纵犯谋逆, 止于狱 中赐尽, 不得市曹行翏, 亦不得连坐支属。赵匡扸想要告诉天下人, 他要建立一个长期稳定 的政权, 并不是 “马上得政权, 马上失政权” ，对于毫无良知的人，新朝同样不欢迎。赵匡 胤的种种举动, 让天下人明白新天子的仁德之心, 以及想要建立稳定政权的愿景。动荡的年 代, 人心思静, 百姓们看到了新朝能够解决唐朝灭亡后长期战乱, 政权更迭使社会秩序和生 产经济受到极为严重的破坏, 民众流离失所, 痛苦莫堪的局面。正是因为宋太祖赵匡㻆为天 下人树立了统一的目标, 那正是百姓的期望。正是因为这个愿景目标, 树立了赵匡胤的威信, 并且激励百姓为了新朝的安定繁荣努力。

\section{2. 下属沟通}

各朝代的开国者无忌讳诸将手中的兵权, 才有了功臣在开国后被诛杀的厄运，有著名的汉朝 开国将领韩信、明朝开国将领李善长等。赵匡胤却以独特的语言技巧成功的避免了这一惨案。 宋朝建国初期, 局势渐渐稳定, 但昔日宋太祖那些心腹、兄弟, 如今都是禁军的高级将领, 实际上已经代替宋太祖成为大宋禁军中最高权势的将领, 成为了宋太祖的心腹大患。在同赵 普商议后, 决定解除石守信、王审琦等人的兵权。在一次郊外狩猎中, 宋太祖先是告诉石守 信等人宋朝目前最大的隐患是诸位将领, 表露自己削权的心志, 再提出人生短暂, 人不过是 自己和子孙后代的荣华富贵。宋太祖告诉将领们, 你们现在辞去禁军的职务, 到地方担任节 度使, 这样可以永享富贵, 并且能够与皇室结亲。这就是著名的 “杯酒释兵权”。赵匡胤凭 借自己与下属成功的沟通，成功解决了兵权的问题，加强了中央集权。

\section{3. 打破陃习, 改革创新}

中唐以来，藩镇割据为祸甚烈，帝王反而倒成了傀儡。赵匡胤采取了一系列措施进行改革。 消除藩镇势力, 从财政入手, “制其钱谷, 收其精兵, 天下自安矣”。北宋的政治制度基本 承袭了唐制，赵匡胤设置新的中央政治权利框架，设置副宰相，与宰相合称 “宰执”，共同 掌管朝政; 设置枢密院, 负责调动军队, 但无军事实权, 使得管军队的将领无调动权利, 调 动军队的没有兵权, 这样一文一武的设置, 分别向皇帝奏事, 互不干预。赵匡胤还设置了 “三 司” ，负责全国的财政，朝廷还建立由皇帝亲自掌管的一套财政机构。这样以上三方面的变 动, 将政权、军权、财权集中于皇帝一身, 加强了皇权的集中。赵匡胤具有改革精神, 不遗 余力的消除各种制度上弊病, 使得新朝以全新的面貌出现在百姓的面前, 在一定程度上激励 了臣民，共同建设新王朝。

\section{3. 结论}

赵匡胤的一生是辉煌的一生, 他凭借自身的鬼米力特质在乱世中带领追随者建立了大宋王朝, 成为后人津津乐道了一代仁君。赵匡胤是个不折不扣的鬼米力型领导, 研究其身上的特质有利 于我们更好的理解魅力型领导，并且塑造自身的人格鬼米力。 


\section{References}

[1]. Robert J. House. A 1976 Theory of charismatic leadership [A] .in J.G. Hunt and L.L. Larson (eds) . Leadership: The cutting

[2]. Robert J. House. Charismatic leadership in service-producing organizations [J] .International Journal of Service Industry Management, 1992, 3 (2) : 5-16.

[3]. Nadler, David A. Tushman,Michael L.. Beyond the Charismatic Leader: Leadership and Organizational Change [J]. California management review, 1990(32): 77-97. 